This item was submitted to Loughborough's Research Repository by the author.

Items in Figshare are protected by copyright, with all rights reserved, unless otherwise indicated.

\title{
Remarks on reply to comments on Chapter 12 of "Railway Noise and Vibration: Mechanisms, Modelling and Means of Control", by D. Thompson (with contributions from C. Jones and P.-E. Gautier), Elsevier, 2009
}

\section{PLEASE CITE THE PUBLISHED VERSION}

http://dx.doi.org/10.1016/j.apacoust.2011.04.006

\section{PUBLISHER}

(C) Elsevier

\section{VERSION}

AM (Accepted Manuscript)

\section{LICENCE}

CC BY-NC-ND 4.0

\section{REPOSITORY RECORD}

Krylov, Victor V.. 2013. "Remarks on Reply to Comments on Chapter 12 of "railway Noise and Vibration: Mechanisms, Modelling and Means of Control", by D. Thompson (with Contributions from C. Jones and P.-E. Gautier), Elsevier, 2009". figshare. https://hdl.handle.net/2134/11362. 
This item was submitted to Loughborough's Institutional Repository (https://dspace.lboro.ac.uk/) by the author and is made available under the following Creative Commons Licence conditions.

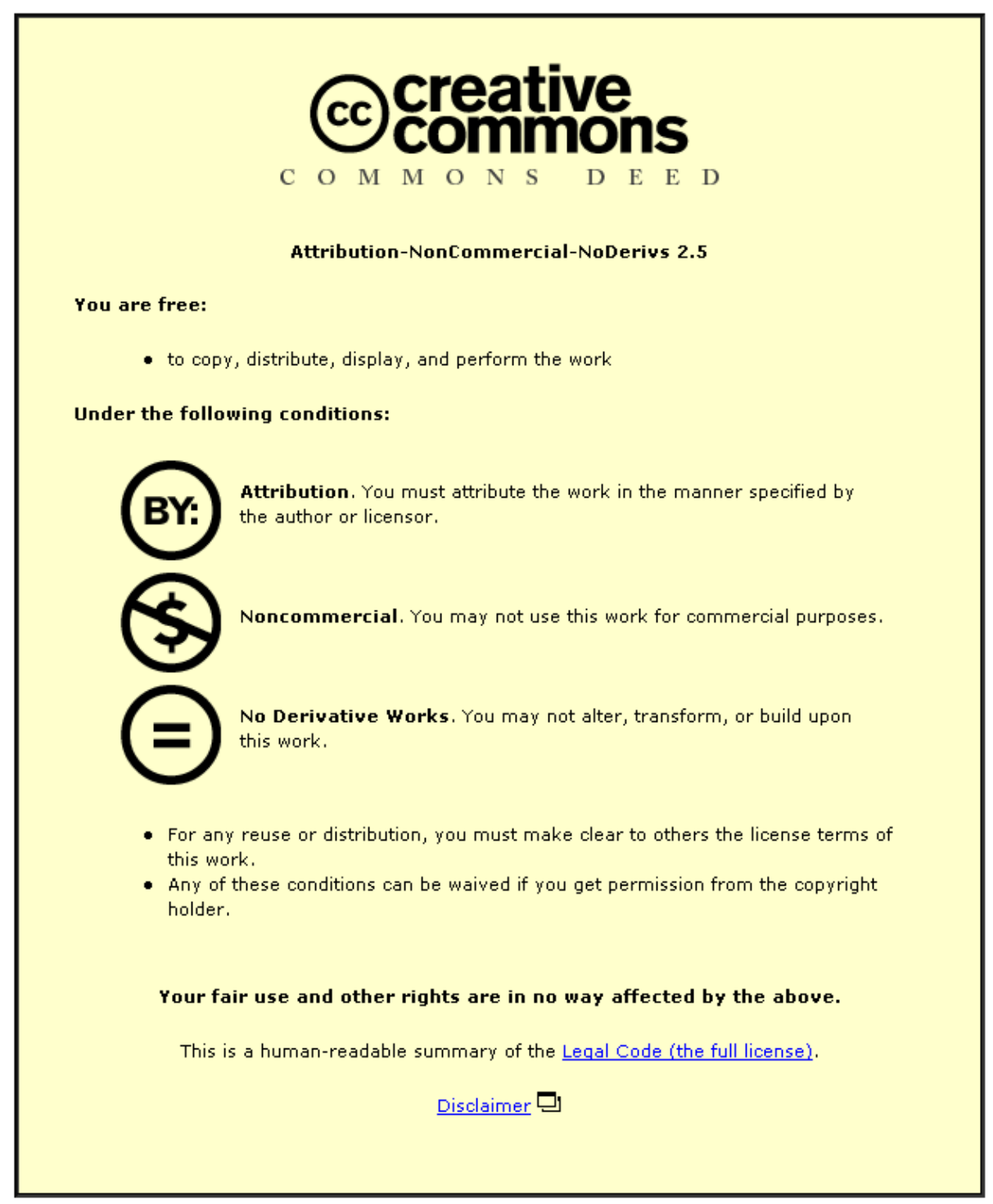

For the full text of this licence, please go to: http://creativecommons.org/licenses/by-nc-nd/2.5/ 


\section{Remarks on reply to comments on Chapter 12 of "Railway Noise and Vibration: Mechanisms, Modelling and Means of Control", by D. Thompson (with contributions from C. Jones and P.-E. Gautier), Elsevier, 2009}

In their reply to my Letter, David Thompson and Chris Jones find nothing wrong with the lack of references concerning the generation of trans-Rayleigh bow waves in Chapter 12 of the book "Railway Noise and Vibration: Mechanisms, Modelling and Means of Control'". Their main arguments are that their book is a 'textbook which does not set out to provide a historical review' and that it has a 'tutorial approach'. However, to me, their book looks more like a research monograph than a textbook, particularly in Chapter 12 where there are few traces of the claimed 'tutorial approach'. Finally, even if such an approach is used, it should strive to give accurate information about who did what and when.

Victor V. Krylov

Department of Aeronautical and Automotive Engineering, Loughborough University, Loughborough, Leicestershire, LE11 3TU, UK E-mail address: $\underline{\text { V.V.Krylov@lboro.ac.uk }}$ 